\title{
Successful Management of Treatment-Resistant Alopecia Areata with Platelet Rich Plasma: A Case Series
}

\author{
Sanjeewani FONSEKA, Y.M.D.M BANDARA, Brabaharan SUBHANI \\ Department of Pharmacology, University of Peradeniya, and Skin Center, Mulgampola, Kandy, Sri Lanka \\ *Correspondence: Sanjeewani Fonseka, E-mail: sanjeewani.fonseka@yahoo.com \\ UDC 616.594.1-085
}

\begin{abstract}
Introduction. Alopecia areata (AA) is an autoimmune disease-causing non-scarring alopecia. It is usually treated with immunosuppressive agents, to which some patients fail to respond adequately. Material and Methods. Three patients with AA refractory to standard therapy were treated with intra-dermal injection of autologous platelet rich plasma (PRP) every four weeks. Results. All three patients showed remarkable improvement after multiple sessions of PRP treatment. Conclusion. Autologous PRP is safe and effective in treatment-resistant forms of AA demonstrated in many case reports; therefore it deserves further study with randomized, placebo-controlled trials.
\end{abstract}

Key words: Alopecia Areata; Platelet-Rich Plasma; Treatment Outcome; Case Reports

\section{Introduction}

Alopecia areata (AA) is an autoimmune disease ranging from a single patch of alopecia to alopecia universalis (1). It is usually treated with topical, intralesional and systemic immunosuppressive drugs (2). Since AA does not always respond to standard treatment, alternative therapies are required.

Platelet rich plasma (PRP) is a concentrate of autologous platelets widely used in various clinical disciplines to promote tissue regeneration. It is now emerging as a treatment for AA with minimal adverse effects (2).

We report the successful treatment of three challenging clinical presentations of alopecia areata with PRP.

\section{Case Reports}

Case 1

A 25-year-old female presented with AA (area of scalp hair loss approximately $75 \%$ ), which has lasted for three years. She had been previously treated with topical steroids, $2 \%$ minoxidil lotion, dithranol paste, $0.1 \%$ tacrolimus ointment, intralesional triamcinolone and several courses of oral prednisolone, dexamethasone, azathioprine and sulfasalazine without success.
Case 2

A 23-year old female presented with alopecia totalis lasting for 6 years. She had undergone topical treatments with steroids, $2 \%$ minoxidil lotion, dithranol paste, $0.1 \%$ tacrolimus ointment, intralesional triamcinolone, intravenous dexamethasone pulses, oral prednisolone, and sulfasalazine. By the time she presented to us there was no progression of the hair loss but there was no new hair growth.

\section{Case 3}

A 55-year-old female presented with alopecial totalis lasting for 4 years. She was treated with topical steroids, dithranol paste, $0.1 \%$ tacrolimus ointment, intralesional triamcinolone acetonide injections, oral prednisolone, intravenous dexamethasone pulses, sulfasalazine and oral methotrexate.

As stated above a fair trial of the available treatment protocols was attempted; however, in spite of it there was continued progression and despite ore-growth of hair it was followed by a relapse of symptoms. We treated these three patients with autologous PRP as mentioned below. 


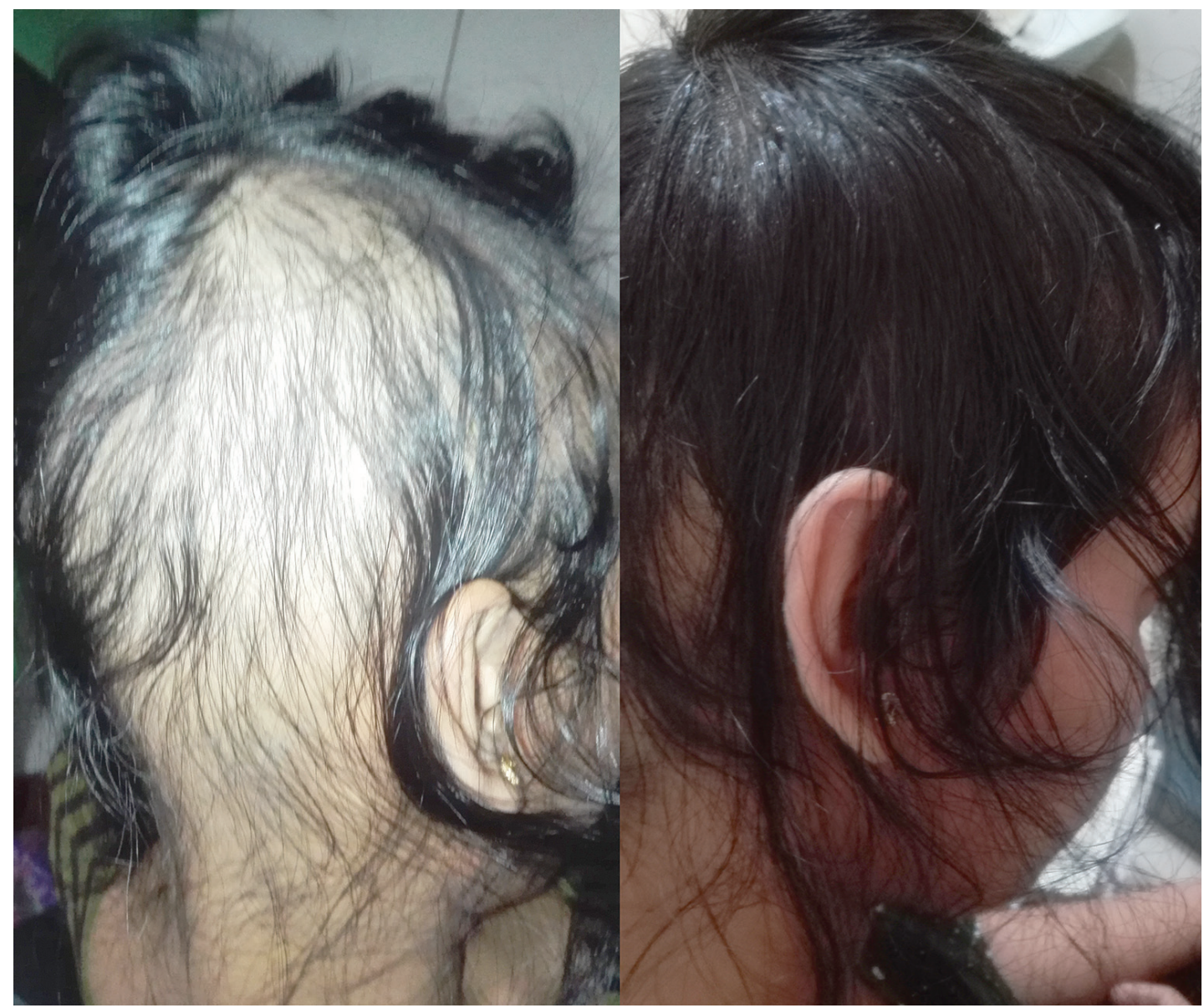

Figure 1. Prior to commencement of therapy and following commencement of therapy

\section{Material and Methods}

Their basic haematological and biochemical investigations were within the normal range. Their thyroid functions were normal and thyroid antibodies were negative. They had no other co-morbidities.

PRP was prepared using $40 \mathrm{ml}$ of each patient's blood using sodium citrate $(9: 1)$ as the anticoagulant. Centrifugation was carried out at $3000 \mathrm{rpm}$ for ten minutes followed by $2000 \mathrm{rpm}$ for five minutes. A total volume of about $10 \mathrm{ml}$ of PRP was injected intradermally to the bald patches on the scalp $1 \mathrm{~cm}$ apart under regional anaesthesia with lignocaine and adrenaline (2\% lignocaine with adrenaline 1:80 000 at a dose of $7 \mathrm{mg} / \mathrm{kg}$ with roughly around $15 \mathrm{ml}$ of lignocaine diluted up to $20 \mathrm{ml}$ with distilled water was used). The procedure was repeated every four weeks until a satisfactory response was obtained.
During the PRP treatment, the patients were advised to apply $5 \%$ minoxidil lotion and topical steroids. No systemic therapy was used.

The treatment was well tolerated by all three patients without side effects. The response to treatment was monitored with global photographs of the scalp at each visit. At the end of the third session, case 1 had showed a marked response with approximately $80 \%$ recovery of scalp hair growth (Figure 1). Case 2 and case 3 demonstrated almost complete recovery of scalp hair growth after the sixth and eighth sessions, respectively.

\section{Discussion}

Alopecia areata $(A A)$ is an autoimmune disease targeting anagen hair follicles leading to non-scarring alopecia ranging from being relatively mild with some patches of hair loss to total loss of scalp (alopecia totalis) and 
body hair (alopecia universalis). It is usually treated with corticosteroids (intralesional, topical and oral), contact immunotherapy, minoxidil and immunosuppressive drugs. Some patients do not respond to any of the above treatment modalities.

PRP is an autologous platelet concentrate suspended in plasma. It is used in many clinical disciplines to promote tissue regeneration. Amongst more than 20 growth factors (GFs) present in PRP, platelet-derived growth factor (PDGF), transforming growth factor- $\beta$ (TGF- $\beta$ ) and vascular endothelial growth factor (VEGF) are mainly responsible for the regenerative action (3).

These GFs bind to receptors of stem cells located in the bulge area of the hair follicles and promote their transformation to hair follicular cells (4). They also cause proliferation of dermal papillary cells (3).The end result is activation and continuation of the anagen phase of the hair cycle $(4,5)$. PDGF and VEGF have angiogenic potential and improve perfusion to hair follicles (6). PRP can be used alone or in combination with other treatment methods (3).

Several randomized, double blind, placebo-controlled, half-head studies in patients with AA have demonstrated increased hair growth after treatment with PRP without major adverse effects. As the effectiveness of PRP in treatment-resistant forms of AA has been demonstrated mainly in case reports, it deserves further study with randomized, placebo-controlled trials. As of now, PRP may be offered as a new and potentially successful treatment for patients with AA who fail to respond to standard therapy (7).

\section{References}

1. Pratt $\mathrm{CH}$, King LE Jr, Messenger AG, Christiano AM, Sundberg JP. Alopecia areata. Nat Rev Dis Primers. 2017;3:17011.

2. Falto-Aizpurua L, Choudhary S, Tosti A. Emerging treatments in alopecia. Expert Opin Emerg Drugs. 2014;19(4):545-56.

3. Maria-Angeliki G, Alexandros-Efstratios K, Dimitris R, Konstantinos K. Platelet-rich plasma as a potential treatment for noncicatricial alopecias. Int J Trichology. 2015;7(2):54-63.

4. Uebel CO, da Silva JB, Cantarelli D, Martins P. The role of platelet plasma growth factors in male pattern baldness surgery. Plast Reconstr Surg. 2006;118(6):1458-67.

5. Li ZJ, Choi HI, Choi DK, Sohn KC, Im M, Seo YJ, et al. Autologous platelet-rich plasma: a potential therapeutic tool for promoting hair growth. Dermatol Surg. 2012;38(7 Pt 1):1040-6.

6. Arshdeep, Kumaran MS. Platelet-rich plasma in dermatology: boon or a bane? Indian J Dermatol Venereol Leprol. 2014;80(1):5-14 .

7. Bagherani N. Is platelet-rich plasma effective in the treatment of alopecia areata? Dermatol Ther. 2016; 29(4):284.

\section{Primena plazme obogaćene trombocitima u uspešnom lečenju alopecije areata otporne na tretman - prikaz serije slučajeva}

\begin{abstract}
Sažetak
Uvod. Alopecija areata je autoimuno oboljenje koje izaziva alopeciju bez ožiljaka. Obično se leči imunospresivnim agensima na koje neki pacijenti ne reaguju adekvatno. Materijal i metode. Tri pacijenta sa alopecijom areata, koji nisu reagovali na standardnu terapiju, lečeni su intradermalnim ubrizgavanjem autologne plazme obogaćene trombocitima svake četiri nedelje. Rezultati. Kod sva tri pacijenta je došlo do primetnog pobolj-
\end{abstract}

Ključne reči: Alopecija areata; Plazma bogata trombocitima; Ishod terapije; Prikazi slučajeva

Received 17.08.2019.

Accepted 5.09.2019. 